\title{
A Case of Chronic Neutrophilic Leukemia with Paraproteinemia (IgG Type $\lambda$ and IgA Type K)
}

\author{
Akiharu Watanabe, MD, Yasuhiro Yoshida, MD, Harumi Yamamoto, MD, \\ Shoji Kimura, MD, Hideo Nagashima, MD and Koichi Kitajima, MD
}

An unusual case of chronic neutrophilic leukemia associated with paraproteinemia (IgG Type $\lambda$ and IgA Type K) was followed for 3 years. Clinical and hematological findings obtained during the entire course fulfil the previously reported criteria for the diagnosis of chronic neutrophilic leukemia. A marked infiltration of mature neutrophils in the spleen and liver was confirmed by postmortem examination.

Key Words: Chronic neutrophilic leukemia, Paraproteinemia, Leukemoid reaction, Chronic myelogenous leukemia

Only a few reports have been published on chronic neutrophilic leukemia which is an uncommon myeloproliferative disorder difficult to distinguish from leukemoid reactions. Recently, we had the opportunity of studying a patient whose condition closely resembled previous clinical and hematological descriptions of chronic neutrophilic leukemia. The case was associated with benign monoclonal gammopathy and double M-proteinemia (IgG Type $\lambda$ and IgA Type K).

\section{CASE REPORT}

A 71-year-old woman complained of general fatigue, abdominal distention and palpitation on effort in April 1980. The patient had been well until then and had no complaint, no past history and no family history of blood disease. She consulted a doctor, at which time hepatosplenomegaly, cardiomegaly, ascites and pretibial edema were pointed out. The initial counts of white blood cells, red blood cells and platelets were $86400 / \mathrm{mm}^{3}, 300 \times 10^{4} / \mathrm{mm}^{3}$ and $5 \times 10^{4} /$ $\mathrm{mm}^{3}$, respectively. She was suspected of having chronic myelogenous leukemia. She had gouty symptoms but no apparent hemorrhagic tendency.
She was admitted to a hospital on May 12, 1980 and received a $400 \mathrm{ml}$ blood transfusion. The patient was then transferred to Okayama University Hospital for further examination on June 2, 1980. Her pulse was 108 and regular, blood pressure $132 / 60 \mathrm{mmHg}$ and body temperature $37.3^{\circ} \mathrm{C}$. The conjunctivae were pale but not icteric. No significant lymphadenopathy was noted. Her apical impulse was found $3 \mathrm{~cm}$ outside the midclavicular line, and there was a slight systolic murmur over the apex area. The spleen was palpable 8 finger-breadths and the liver 3 finger-breadths below the respective costal margins. No other mass was felt. There was slight pretibial edema. The results of a neurological examination were normal.

Laboratory studies on admission revealed 8.0 $\mathrm{g} / \mathrm{dl}$ hemoglobin, a hematocrit reading of $23.0 \%$, $224 \times 10^{4} / \mathrm{mm}^{3}$ red blood cells and $77600 / \mathrm{mm}^{3}$ white blood cells, with $66.0 \%$ segmented neutrophils, $23.0 \%$ band forms, $0.5 \%$ myelocytes, $0.5 \%$ metamyelocytes, $6.5 \%$ lymphocytes, $3.0 \%$ monocytes and $0.5 \%$ eosinophil. A view of the peripheral blood smear is shown in Fig. 1. The neutrophils had Döhle bodies and prominent

From the First and the Second Department of Internal Medicine, Okayama University Medical School, Okayama. Received for publication March 7, 1983.

Reprint request to: Akiharu Watanabe, MD: The First Department of Internal Medicine, Okayama University Medical School, 2-5-1 Shikata-cho, Okayama, 700, Japan. 


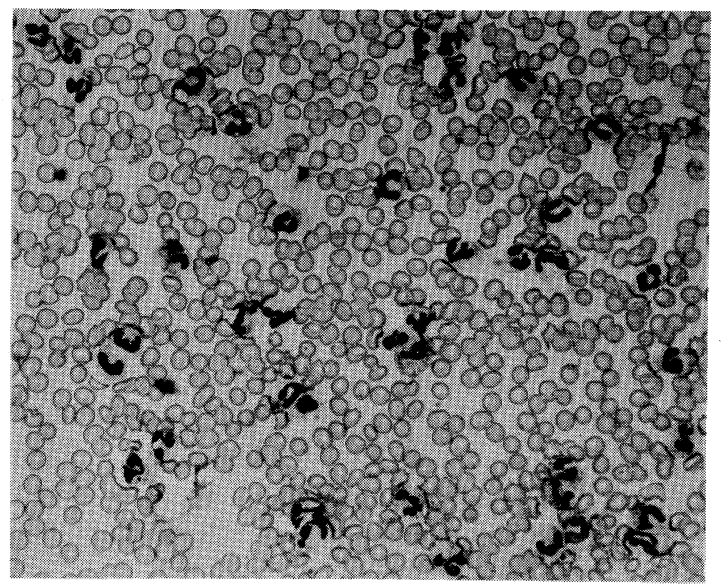

Fig. 1. Peripheral blood smear showing obvious neutrophilic leukocytes.

toxic granules. The erythrocytes showed mild anisocytosis. The mean corpuscular volume (MCV) was $102 \mu^{3}$, mean corpuscular hemoglobin (MCH) $36.1 \mathrm{pg}$ and mean corpuscular hemoglobin concentration (MCHC) $34.0 \%$, indicating macrocytic and hyperchromic anemia. Reticulocytes were $0.7 \%$ and platelets $4.5 \times 10^{4} / \mathrm{mm}^{3}$. Bleeding time was $4 \mathrm{~min}$, Rumpel Leede positive and clot retraction $60 \mathrm{~min}$. Erythrocyte sedimentation rate (ESR) was $37 \mathrm{~mm} / \mathrm{hr}$. The urine showed neither albumin nor Bence-Jones protein. Microscopic examination of urine sediment revealed no abnormality. BUN was $15.0 \mathrm{mg} / \mathrm{dl}$, FBS 82 $\mathrm{mg} / \mathrm{dl}$ and uric acid $10.7 \mathrm{mg} / \mathrm{dl}$ (normal 3.07.6). Serum electrolytes were normal. Total serum protein was $6.3 \mathrm{~g} / \mathrm{dl}$ with $3.6 \mathrm{~g}$ albumin,
$0.2 \alpha_{1}$-globulin, $0.4 \mathrm{~g} \alpha_{2}$-globulin, $0.7 \mathrm{~g} \beta$-globulin, $1.1 \mathrm{~g} \mathrm{M}$-protein and $0.4 \mathrm{~g} \gamma$-globulin. Immunoglobulin G (IgG) concentrations were $1447 \mathrm{mg} / \mathrm{dl}$ (normal 935-2002), IgA 453 (170-338) and IgM $75 \mathrm{mg} / \mathrm{ml}$ (63-165). The M-components were IgG (Type $\lambda$ ) and IgA (Type K) as determined by immunoelectrophoresis. Indirect and direct Coombs tests were negative. Serum total bilirubin was $0.44 \mathrm{mg} / \mathrm{dl}$, cholesterol $49 \mathrm{mg} / \mathrm{dl}$, ester cholesterol $34 \mathrm{mg} / \mathrm{dl}$ (E/T, 69\%), GOT $15 \mathrm{IU}$, GPT $20 \mathrm{IU}$, alkaline phosphatase (AlPase) 9.9 BLU (high proportion of Isozymes 1 and 2), LAP 222 IU, $\gamma$-GPT 162 IU (normal 3-35), LDH 267 IU (high proportion of Isozymes 4 and 5), ChEase $0.68 \Delta \mathrm{pH}, \mathrm{K}_{\mathrm{ICG}} 0.19$, prothrombin time 13.1 sec, thrombotest $44.3 \%$ and normotest $56.5 \%$. Serum iron was $189 \mu \mathrm{g} / \mathrm{dl}$ with a total iron-binding capacity of $203 \mu \mathrm{g} / \mathrm{dl}$ (normal 270-370). Fibrinogen was $260 \mathrm{mg} / \mathrm{dl}$, AFP $1 \mathrm{ng} / \mathrm{ml}$ and CEA $2 \mathrm{ng} /$ ml. Serum vitamin $B_{12}$ was more than $3200 \mathrm{pg} /$ $\mathrm{ml}$ (normal 300-1000) and serum lysozyme activity $73.8 \mu \mathrm{g} / \mathrm{ml}$ (normal 5.0-10.2). Neutrophil AlPase (NAP) was extremely high, with a score of 498 in June and 499 in July (control 171-321). Granulocyte function was examined, and it was found that superoxide production was somewhat low ( $74 \%$ of the control) but myeloperoxidase activity $100 \%$ of the control. Colony-forming units in culture (CFU-c) were very low and the colony-stimulating factor (CSF) was high according to the Robinson-Pike method ${ }^{9}$. Bone marrow aspiration revealed a hypercellular marrow with

Table 1. Bone marrow smears during clinical course

\begin{tabular}{|c|c|c|c|c|c|c|c|c|c|c|c|c|c|c|c|}
\hline \multirow[t]{2}{*}{ Date } & \multirow{2}{*}{$\begin{array}{l}\text { Total } \\
\text { nucleated } \\
\text { cells } \\
\left(\times 10^{4} / \mathrm{mm}^{3}\right)\end{array}$} & \multirow[t]{2}{*}{$\begin{array}{l}\text { Blast } \\
\text { cells }\end{array}$} & \multirow[t]{2}{*}{$\begin{array}{l}\text { Promye } \\
\text { locytes }\end{array}$} & \multirow[t]{2}{*}{$\begin{array}{l}\text { Myelo } \\
\text { cytes }\end{array}$} & \multirow[t]{2}{*}{$\begin{array}{l}\text { Meta } \\
\text { myelo } \\
\text { cytes }\end{array}$} & \multicolumn{2}{|c|}{$\begin{array}{l}\text { Polymorho } \\
\text { nuclear } \\
\text { neutrophils }\end{array}$} & \multirow[t]{2}{*}{$\begin{array}{l}\text { Eosino } \\
\text { phils }\end{array}$} & \multirow[t]{2}{*}{$\begin{array}{l}\text { Baso } \\
\text { phils }\end{array}$} & \multirow[t]{2}{*}{$\begin{array}{l}\text { Mono } \\
\text { cytes }\end{array}$} & \multirow[t]{2}{*}{$\begin{array}{l}\text { Lympho } \\
\text { cytes }\end{array}$} & \multirow[t]{2}{*}{$\begin{array}{l}\text { PIasma } \\
\text { cells }\end{array}$} & \multirow[t]{2}{*}{$\begin{array}{l}\text { Pro } \\
\text { erythro } \\
\text { cytes }\end{array}$} & \multirow[t]{2}{*}{$\begin{array}{l}\text { Normo } \\
\text { blasts }\end{array}$} & \multirow[t]{2}{*}{$M / E$} \\
\hline & & & & & & $\begin{array}{l}\text { Band } \\
\text { form }\end{array}$ & $\begin{array}{l}\text { Segmented } \\
\text { form }\end{array}$ & & & & & & & & \\
\hline
\end{tabular}

\begin{tabular}{|c|c|c|c|c|c|c|c|c|c|c|c|c|c|c|c|}
\hline $\begin{array}{l}\text { June } 2 \\
1980\end{array}$ & & 0 & 7.6 & 2.4 & 5.2 & 24.0 & 44.6 & 0.4 & 0.4 & 1.6 & 12.0 & 0.8 & 0.8 & 0 & 105 \\
\hline $\begin{array}{l}\text { June } 20 \\
1980\end{array}$ & 30.2 & 0.6 & 9.4 & 5.0 & 9.0 & 31.0 & 37.8 & 0.2 & 0.4 & 1.8 & 3.0 & 0.2 & 0.4 & 1.0 & 66 \\
\hline $\begin{array}{l}\text { August } 4 \\
1980\end{array}$ & 33.0 & 0.6 & 16.0 & 7.0 & 13.2 & 28.6 & 24.8 & 0.4 & 0.2 & 0.8 & 6.2 & 0.4 & 0.2 & 1.4 & 56 \\
\hline $\begin{array}{l}\text { December II } \\
1980\end{array}$ & 16.0 & 1.2 & 3.8 & 12.0 & 11.4 & 27.4 & 26.0 & 0.4 & 0 & 2.2 & 8.8 & 0 & 0.8 & 6.0 & 12 \\
\hline $\begin{array}{l}\text { March } 5 \\
1981\end{array}$ & 13.8 & 2.2 & 3.4 & 8.4 & 7.8 & 33.8 & 36.0 & 0 & 0 & 2.2 & 3.6 & 0 & 0.4 & 2.2 & 35 \\
\hline $\begin{array}{l}\text { March } 3 \\
1982\end{array}$ & 28.6 & 1.6 & 3.2 & 3.6 & 13.2 & 30.4 & 40.4 & 0.2 & 0.2 & 1.8 & 3.8 & 0 & 0.2 & 1.2 & 66 \\
\hline
\end{tabular}




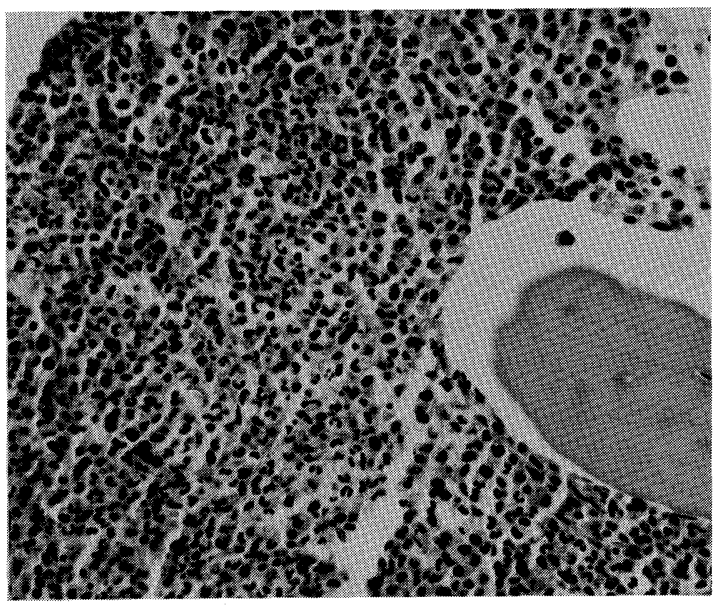

Fig. 2. Bone marrow biopsy showing increased cellularity and no evidence of fibrosis.

hyperplasia of myeloid elements and with a myeloid-erythroid ratio (M/E) of 105; mature neutrophils were prominent (Table 1). Megakaryocytes were mature and slightly decreased in relative number. Normal connective tissues were observed in the bone marrow biopsy (Fig. 2). The karyotype of all blood and bone marrow cells examined was $46 \mathrm{XX}$, with no Philadelphia chromosomes $\left(\mathrm{Ph}^{1}\right)$ being found. A chest-X-ray showed an enlarged heart with CTR of $58 \%$.
An electrocardiogram indicated sinus tachycardia and left BBB. The abdominal computed-tomography demonstrated hepatic enlargement in addition to the splenomegaly. An upper gastrointestinal series, barium enema, cholecystogram (DIC) and intravenous pyelography were all within normal limits. Gynecological examinations showed no malignant tumors. Scintiscans of the bone and bone X-rays of the entire body were normal. Cultures of blood, urine and bone marrow were repeatedly negative.

She was transfused with 2 units of packed red cells with marked symptomatic improvement. No fever was recorded during the entire clinical course, except for several days following admission. She had received no chemotherapy. The patient had no complaints and was discharged on November 28, 1980 to be followed in the outpatient clinic. The patient did well at home, maintaining her hemoglobin between 10 and 12 $\mathrm{g} / \mathrm{dl}$ by infusing one unit of packed red cells every 5 months (Table 2 ).

She suddenly complained of high fever and dyspnea on June 10, 1982 and was immediately admitted to Fukuyama City Hospital. The patient had ascites and pretibial edema and received antibiotics, diuretics and digitalis. However, she died

Table 2. Peripheral blood and blood biochemistry during clinical course

\begin{tabular}{|c|c|c|c|c|c|c|c|c|c|c|c|c|c|c|c|}
\hline \multirow[t]{2}{*}{ Date } & \multirow{2}{*}{$\begin{array}{r}\mathrm{RBC} \\
\left(\times 10^{4}\right) \\
\left.\mathrm{mm}^{3}\right)\end{array}$} & \multirow{2}{*}{$\begin{array}{c}\mathrm{Hb} \\
(\mathrm{g} / \mathrm{d} 1)\end{array}$} & \multirow{2}{*}{$\begin{array}{c}\text { WBC } \\
\left(\times 10^{4} / \mathrm{mm}^{3}\right)\end{array}$} & \multicolumn{3}{|c|}{ Differential } & \multirow[b]{2}{*}{$\begin{array}{l}\text { Lympho } \\
\text { cyte }\end{array}$} & $\begin{array}{l}\text { Plate } \\
\text { lets }\end{array}$ & \multirow{2}{*}{$\begin{array}{l}\text { Reti } \\
\text { culo } \\
\text { cyte }\end{array}$} & \multirow[t]{2}{*}{ SGPT } & \multirow{2}{*}{$\begin{array}{l}\text { Alpase } \\
\text { (BLU) } \\
(\mathrm{IU})^{*}\end{array}$} & \multirow{2}{*}{$\begin{array}{l}\gamma \text {-GTP } \\
\text { (IU) }\end{array}$} & \multirow{2}{*}{$\begin{array}{l}\text { Chole } \\
\text { sterol } \\
\text { (mg/al) }\end{array}$} & \multirow{2}{*}{$\begin{array}{l}\text { Uric } \\
\text { acid } \\
\text { (mg/dl) }\end{array}$} & \multirow{2}{*}{$\begin{array}{l}\text { M-Protein } \\
\text { (g/dl) }\end{array}$} \\
\hline & & & & $\begin{array}{l}\text { Meta } \\
\text { myelo } \\
\text { cyte }\end{array}$ & $\begin{array}{l}\text { Band } \\
\text { form } \\
\text { (8) }\end{array}$ & $\begin{array}{l}\text { Seg } \\
\text { mented } \\
\text { form }\end{array}$ & & $\left(\times 10^{4} / \mathrm{mm}^{3}\right)$ & & & & & & & \\
\hline $\begin{array}{l}\text { July } 7 \\
1980\end{array}$ & 309 & 7.9 & 11.7 & 2 & 47 & 43 & 6 & & 1.2 & 10 & 14.4 & 188 & 62 & 5.8 & 1.3 \\
\hline $\begin{array}{l}\text { August } 14 \\
1980\end{array}$ & 268 & 7.2 & 12.6 & 1 & 54 & 36 & 8 & 5.8 & 0.9 & 44 & 17.8 & 163 & 58 & 7.7 & 1.5 \\
\hline $\begin{array}{l}\text { November } \\
1980\end{array}$ & $12 \quad 269$ & 9.0 & 8.9 & 0 & 54 & 34 & 10 & 5.4 & & 22 & 13.9 & & 69 & 8.2 & 1.6 \\
\hline $\begin{array}{l}\text { April 21 } \\
1981\end{array}$ & 270 & 7.6 & 11.0 & 1 & 35 & 57 & 7 & 3.5 & 3.1 & 9 & 43.2 & 82 & & 9.5 & \\
\hline $\begin{array}{l}\text { August } 11 \\
1981\end{array}$ & 301 & 10.2 & 7.1 & 1 & 15 & 65 & 13 & 5.0 & 2.5 & 24 & 45.5 & 124 & & 10.4 & \\
\hline $\begin{array}{l}\text { December } \\
1981\end{array}$ & 26326 & 11.2 & 7.6 & 0 & 35 & 57 & 6 & 6.9 & & 117 & $668^{*}$ & 173 & 84 & 9.4 & 1.5 \\
\hline $\begin{array}{l}\text { May } 24 \\
1982\end{array}$ & 276 & 10.3 & 11.2 & 0 & 42 & 41 & 7 & & & 89 & $701^{*}$ & 203 & 71 & 6.5 & \\
\hline
\end{tabular}


of heart failure on the fifth day after admission, 3 years and 2 months from the onset of the disease. An autopsy could not be performed, but postmortem biopsy of the spleen and liver was made. The liver bile ductules and sinusoids were infiltrated with mature neutrophils, but immature myelocytes were not seen in portal tracts. Bile stasis was not present. Splenic sinusoids were also infiltrated with mature neutrophils (Fig. 3). No bacterium was cultured from either biopsied specimen.

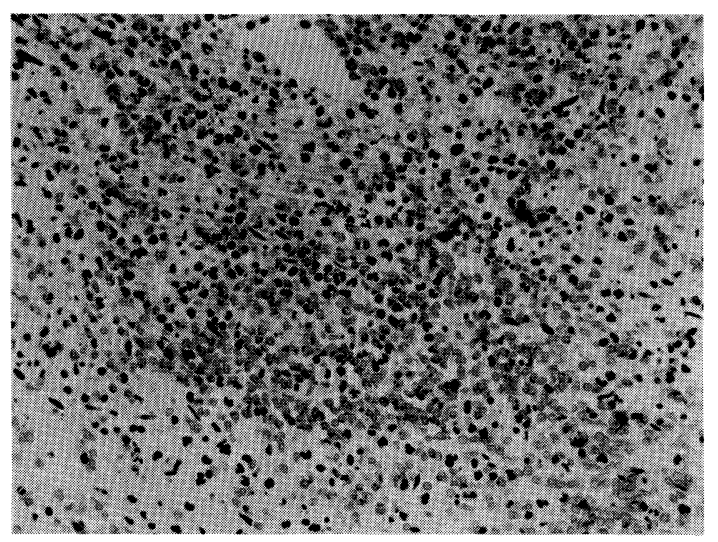

Fig. 3. Histological findings of the spleen. Splenic sinusoids were infiltrated with mature neutrophils.

\section{COMMENTS}

Exton-Smith ${ }^{1)}$ reported a case of myeloproliferative syndrome manifested as neutrophilic leukemia, a term used by Jackson and Clark ${ }^{2}$ in describing their cases. Tanzer et al. ${ }^{3}$ ) and Rubin $^{4}$ each used the name chronic neutrophilic leukemia. The term chronic granulocytic leukemia, neutrophilic type, was sometimes used as a synonym for chronic neutrophilic leukemia ${ }^{5)}$. In the present paper, the term chronic neutrophilic leukemia was used. The most important criterion of the disease is its differentiation from a reactive leukemoid state. Whitby and Britton ${ }^{6}$ ) reported two similar cases, which had no evidence of leukemic infiltration of the organs postmortem. Therefore, to the clinical criteria must be added anatomical evidence of organ infiltration by abnormal numbers of granulocytes for final proof that the disease state was not a leukemoid reac- tion. Distinction of chronic neutrophilic leukemia from chronic myelogenous leukemia is sometimes difficult; one previous report described a few patients with chronic myelogenous leukemia who had normal or elevated NAP even in the blastic crises and in remission but did not have bacterial infection ${ }^{7)}$. Chronic myelogenous leukemia patients without $\mathrm{Ph}^{1}$ or other chromosomal abnormalities have also been reported to live longer than those with $\mathrm{Ph}^{1,8)}$.

No increased proportion of myeloblasts, no fibrosis in the bone marrow, but very high NAP scores and an absence of the $\mathrm{Ph}^{1}$ chromosome in the peripheral and bone marrow were noted in the present case. In chronic myelogenous leukemia, colony-forming cells differentiating to granulocytes grow both in the bone marrow and the peripheral blood ${ }^{9)}$. Thus the decrease in colony-forming units observed in this case is in clear contrast with chronic myelogenous leukemia. Döhle bodies and basophilic spots observed in leukocytes in this case are consistent with other reports of chronic neutrophilic leukemia ${ }^{4)}$. The lack of fever, infection and neoplasm, and the presence of hepatosplenomegaly also suggest chronic neutrophilic leukemia. There was no increase in the plasma cells of the bone marrow, which suggests that multiple myeloma was not involved. A search for an underlying cause of a leukemoid reaction related to disseminated tuberculosis, carcinomatosis or splenic abscess was unsuccessful. Therefore, this case is considered to be an example of chronic neutrophilic leukemia. The diagnosis was further supported by the postmortem biopsy evidence of abnormal neutrophilic infiltration of the liver and spleen, from which no organism was cultured.

There are several reports on Japanese cases in the recent literature ${ }^{10-18)}$ (Table 3). Although their ages ranged from 57 to 74 years, most of the patients were over 65 years old. Life spans of those who died of the disease ranged from 2 months to 5 years after deterioration of the patients' condition or apparent onset of the disease. The major causes of death were bleeding and infection. The disease of one patient progressed to a polycytemia vera-like disorder about 2 years after the apparent onset of the illness ${ }^{17}$. 
Table 3. Reported cases of chronic neutrophilic leukemia in Japan

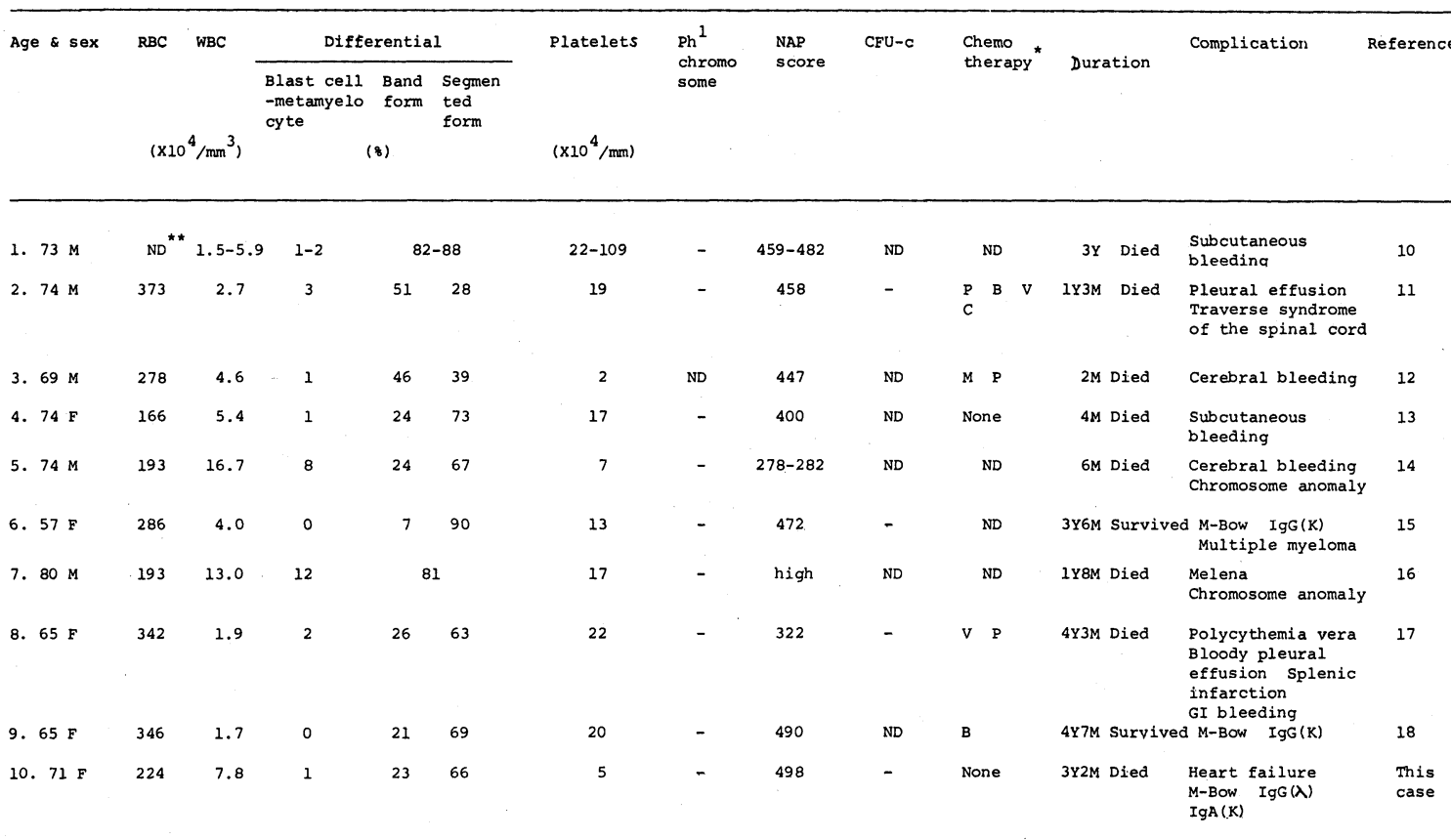

*P: prednisolone B: busulfan $\quad$ V: vincristine $\quad$ C: cytosine arabinoside $\quad$ M: 6-mercaptopurine **ND: not described.

The leukocyte counts in the patients ranged from 15000 to more than $167000 / \mathrm{mm}^{3}$, and granulocytes accounted for 79 to $97 \%$ of the total cells present. A small number of less mature cells, usually myelocytes and metamyelocytes, were initially present in some cases of the disease. The hyperplasia of the bone marrow was mostly myeloid, though myeloid-erythroid ratios were variable. The chromosome anomaly, $47 \mathrm{XY}+\mathrm{C}$, which is observed sometimes in acute leukemia and acute crisis of chronic myelogenous leukemia, was found in 2 patients ${ }^{14,15)}$, and another patient died with acute crisis-like symptoms ${ }^{11)}$. This evidence suggests that chronic neutrophilic leukemia is a myeloproliferative disorder.

The high values of serum AlPase and $\gamma$-GTP observed in the present case may be explained from the fact that an infiltration of the bile ductules by mature neutrophils was observed. Cases with paraproteinemia $\left(\operatorname{IgA~} \mathrm{K}^{5)}\right.$ and IgG $\mathrm{K}^{15,18)}$ ) have been reported previously as in the present communication. Amyloidosis and other pathological conditions such as macroglobu- linemia, chronic lymphocytic leukemia or lymphoma were not found in our case. It is conceivable, therefore, that paraprotein produced by a new clone appeared during the prolonged course of the disease. It is not known, however, whether or not the two diseases of this patient are a chance association.

\section{REFERENCES}

1) Exton-Smith AN, Chazan AA: Myeloproliferative syndrome presenting as neutrophilic leukemia. Proc Soc Med 50: 510, 1957.

2) Jackson IMD, Clark RM: A case of neutrophilic leukemia. Am J Clin Sci 249: 72, 1965.

3) Tanzer J, Harel P, Boiron M, et al: Cytochemical and cytogenic findings in a case of chronic neutrophilic leukemia of mature cell type. Lancet I: 387, 1964.

4) Rubin H: Chronic neutrophilic leukemia. Ann Int Med 65: 93, 1966.

5) Vorobiof DA, Benjamin J, Kaplan H, et al: Chronic granulocytic leukemia, neutrophilic type, with paraproteinemia (IgA Type K). Acta Haemat 60: $316,1978$.

6) Whitby L, Britton CJC: Disorders of the blood. 9th edition, London, $\mathrm{J}$ and Charchill, 1963, $\mathrm{p}$ 
574 and 441.

7) Koler RD, Seaman AJ, Osgood EE, et al: Myeloproliferative diseases, diagnostic value of the leukocyte alkaline phosphatase test. Am J Clin Path 30: 295, 1958.

8) Whang-Peng J, Canellos GP, Carbone PP, et al: Clinical implication of cytogenic variants in chronic myelocytic leukemia. Blood 32: 755, 1968.

9) Pike BL, Robinson WA: Human bone marrow colony growth in agar-gel. J Cell Physiol 76: 77, 1970.

10) Takeshita K, Toyoda S, Takahara K: A case with chronic neutrophilic leukemia. Rinsyo Ketsueki 13: 666, 1972.

11) Shibata A, Shindo $T$, Usui $T$, et al: Chronic neutrophilic leukemia. Nippon Izishinpo 2777: 24, 1976.

12) Kawamura $Y$, Nakanuma $Y$, Suzuki S, et al: A case with chronic neutrophilic leukemia. Rinsyo Ketsueki 20 (Suppl): 105, 1978.
13) Kondo, $Y$, Inaba $H$, Yokoyama $Y$, et al: A case with chronic neutrophilic leukemia. Rinsyo Ketsueki 20: 105,1978 .

14) Aoki I, Toyama K, Tsuchida T, et al: A case of chronic neutrophilic leukemia. Clin Hematol 20: $777,1979$.

15) Nakahara $K$, Ohashi $T$, Kariya $T$, et al: A case of chronic neutrophilic leukemia associated with multiple myeloma. Nihon Ketsueki Gakkai Zasshi $41: 217,1978$.

16) Kyo $\mathrm{Y}$, Ihara $\mathrm{A}$, Okita $\mathrm{H}$, et al: A case with chronic neutrophilic leukemia. Rinsyo Ketsueki 21 (Suppl): 249, 1979.

17) Shirakura T, Murai $Y$, Takahashi $R$, et al: A case of chronic neutrophilic leukemia associated with polycythemia. Rinsyo Ketsueki 20: 943, 1979.

18) Takeuchi $Z$, Kikuoka $M$, Takeo $H$, et al: A case of chronic neutrophilic leukemia associated with benign monoclonal gammanopathy. Rinsyo Ketsueki 20: 1187, 1981. 